\title{
A CDESSCONSTRUÇÃO DA MATERNIDADE NO ROMANCE COM ARMAS SONOLENTAS, DE CAROLA SAAVEDRA
}

\author{
THE CDEJCONSTRUCTION OF MOTHERHOOD IN THE NOVEL COM ARMAS SONOLENTAS, BY CAROLA \\ SAAVEDRA
}

\section{RESUMO}

Experiência exclusivamente delas, a maternidade, assentada nos pilares do patriarcado, constitui-se como uma das ferramentas para o cerceamento das identidades femininas na medida em que funciona, entre outras frentes, como mecanismo regulatório de ação no espaço público. Insurgem-se daí questões fundamentais sobre o direito feminino de arbitrar o próprio corpo e da relação entre mães e filhos/as. Na esteira deste pensamento, e considerando que o meio literário se constitui como espaço para (re)significar comportamentos e posições, o presente artigo pretende apresentar uma leitura interpretativa do romance Com armas sonolentas (2018), de Carola Saavedra, com o objetivo de problematizar a representação da maternidade e seus desdobramentos no âmbito literário. Direcionamos a atenção, em nossa leitura, para a personagem Anna Marianni porquanto seu comportamento mostra-se combativo aos ideais sociais que enxergam a maternidade como único destino de toda mulher, ao mesmo tempo em que impelem aquelas que optam por uma vida sem filhos/as à condição deficitária nos quesitos de feminilidade e amor. Para tanto, embasamos nossas discussões em autores/as como Badinter (1985, 2011), Beauvoir (2016a; 2016b), Donah (2017), Iaconelli (2015), entre outros/as.

Palavras-chave: Maternidade. Literatura de mulheres. Carola Saavedra.

\begin{abstract}
Exclusive experience of women, motherhood, based on the pillars of patriarchy, constitutes one of the tools for curbing female identities as it works, among other fronts, as a regulatory mechanism for action in the public space. This raises fundamental questions about the female right to arbitrate her own body and the relationship between mothers and their children. In the wake of this thought, and considering that the literary medium constitutes a space to (re)signify behaviors and positions, this research intends to present an interpretative reading of the novel Com armas sonolentas (2018), by Carola Saavedra, in order to problematize the representation of motherhood and its developments in the literary sphere. In our reading, we focus on the character Anna Marianni because her behavior is combative with the social ideals that see motherhood as the only destiny of
\end{abstract}

André Eduardo Tardivo

Universidade Estadual de Maringá (UEM). E-mail: tardivo.andre@gmail.com

Lúcia Osana Zolin

Universidade Estadual de Maringá (UEM). E-mail: luciazolin@yahoo.com.br 
every woman, while impelling those who choose a childless life to the deficient condition in terms of femininity and love. For this, we base our discussions on authors such as Badinter (1985, 2011), Beauvoir (2016a; 2016b), Donah (2017), Iaconelli (2015), among others.

Keywords: Motherhood. Women's literature. Carola Saavedra.

\section{Primeiras considerações}

A maternidade tomada como dom integrante da natureza feminina, em certo sentido, consiste em uma das inumeráveis imposições e cerceamentos a que as mulheres estiveram sujeitas ao longo de sua história e, em alguma medida, apesar das numerosas conquistas empreendidas pelos movimentos feministas, ainda estão. A literatura de autoria feminina - ela mesma uma seara historicamente cerceada às mulheres - vem abordando e problematizando com muita pertinência temáticas como sexualidade feminina, relações familiares, mercado de trabalho e, dentre outras que impactam diretamente no modo de estar da mulher na sociedade, a maternidade. São decorrentes da imposição da maternidade (objetivo da existência feminina), assim como da capacidade de maternar (“dom” exclusivamente feminino), as jornadas duplas - e até mesmo as triplas - a que as mulheres-mães precisam se submeter para manterem-se no mercado de trabalho e, ao mesmo tempo, desempenharem os papéis a elas secularmente imputados a fim de que a sobrevivência e o bom desenvolvimento dos/as filhos/as sejam garantidos. É esse estado de coisas que impelem as mulheres a lutarem pelo direito à voz e a fazer escolhas, na tentativa de sobreporem-se à misoginia dos constructos sociais empenhados em confiná-las no interior dos muros das casas, às voltas com as funções de dona-de-casa e as ditas "maternas".

Durante muitos anos, a maternidade foi tida como destino feminino, projeto compulsório de vida comum a todas as mulheres, logo não abraçá-la como meta implicaria inserir-se no rol de mulheres incompletas ou portadoras de alguma patologia física e/ou psíquica. É a partir da revolução cultural empreendida pela segunda onda do feminismo (anos 1960 nos Estados Unidos) que as mulheres conquistam o direito de gerir a própria sexualidade, consequentemente, o direito de decidir se deseja ou não lançar mão de sua capacidade reprodutiva. É o direito de ir e vir na sociedade, outorgado constitucionalmente a todos/as os/as cidadãos/as, associado com o trabalho externo já praticado pelas mulheres, que a maternidade, no âmbito individual, adquire novos entendimentos e passa a ser tomada como escolha. 
Em Com armas sonolentas ${ }^{1}$ (2018), Carola Saavedra, os/as personagens estão, a todo o momento, em trânsito, seja em nível espacial e/ou identitário, o que, do nosso ponto de vista, repercute no modo como a maternidade é experienciada de maneiras diferentes nas cinco gerações de mulheres que compõem o romance. Na realidade extraliterária, não nos parece forçado especular que os constantes deslocamentos empreendidos pelas mulheres, de um lado, e, de outro, a sua inserção em um mundo predominantemente masculino ressignificam a forma como enxergam a si mesmas e a relação que estabelecem com a maternidade. Do mesmo modo que, nesse último romance da escritora, o constante estar em trânsito das personagens contribui para uma nova percepção da maternidade e das formas de maternagem, bem como de si próprias.

O romance é dividido em duas partes e apresenta a trajetória de várias gerações de mulheres que precisam/são impelidas a se deslocarem de um lugar para outro em decorrência de situações econômicas, sociais, emocionais e profissionais, ao mesmo tempo em que a gravidez e a maternidade se tornam realidades com as quais precisam lidar. Em uma analogia gestacional, percebemos um movimento inverso na relação título-temática, porquanto as primeiras narrativas, englobadas pelo título 'O lado de fora', conotam as gestações próprias das personagens, isto é, as interiores, na medida em que estão engendradas no autoconhecimento propiciado pelas experiências com o espaço ocupado. Da mesma maneira, a metade final, reunida pelo título 'O lado de dentro', evidencia o reflexo da experiência interior com o mundo exterior na construção das identidades femininas que transitam na narrativa. É significativo que todas as mães do romance não sejam nominadas ou, no caso de Anna, assuma um pseudônimo, denotando a situação a que toda e qualquer mulher pode estar inserida, além de, no caso da atriz, evidenciar a recusa de sua vida anterior e a construção de novas identidades. Cientes da pluralidade de interpretações e formas de maternagem, propomo-nos a analisar as relações maternas presentes no romance, com foco na personagem Anna. Isso porque as relações que ela estabelece com os que a cercam e com a filha mostram-se fortemente combativas no que diz respeito à maternidade compulsória desenhada nos moldes do patriarcado, colocando em xeque a ideia de "vocação natural" da mulher em gerar e nutrir a vida. A trajetória da personagem promove o desnudamento de que as expectativas geradas no seu entorno relacionadas ao bom desempenho materno são constructos históricos e sociais, suscitando discussões sobre os papéis femininos em uma sociedade que ainda insiste em direcionar as mulheres para caminhos pré-determinados mantendo o status quo da diferença hierarquizada entre os sexos.

\footnotetext{
1 O romance apresenta a trajetória de cinco gerações de mulheres (Avó, mãe, avó, Anna e Maike) que lidam com a maternidade de forma díspar enquanto buscam seus lugares no mundo. Focalizado, principalmente, nas três últimas mulheres da família, o romance ambienta-se na Alemanha e no Rio de Janeiro e acompanha o percurso dessas mulheres distintas e ao mesmo tempo tão próximas que lutam para se (re)encontrarem enquanto sujeitos. A avó, em sua jornada materna em espaços desconhecidos e à mercê dos patrões é condicionada a abrir mão do contato com a filha; Anna, uma jovem que larga tudo pelo casamento e pelo sonho de se tornar uma atriz famosa, abandona a filha recém-nascida num parque na Alemanha por não aceitar a maternidade em sua vida. Por fim, Maike, na procura de suas origens, vem ao Brasil para se (re)encontrar. Ao final, durante o espetáculo de Anna, no teatro, a avó, acompanhada do espectro de sua própria Avó, e Maike se encontram na entrada.
} 


\section{Anna: "a mulher antes da mãe"}

O exercício da maternidade, conforme nos ensinam Elizabeth Badinter (2011) e Leite (2019), não segue um caminho reto e previsível, muito pelo contrário, são justamente as curvas imprevisíveis que fazem com que essa experiência seja única na vida das mulheres. Algumas vertentes sociológicas buscaram na fisiologia a confirmação para o suposto instinto materno das mulheres, porém é inviável classificar a maternagem ${ }^{3}$ como decorrência direta da reprodução, até mesmo porque, desta maneira, reduziríamos a experiência feminina a dois polos - as mães e as mulheres "fracassadas" - sem levar em conta as nuances da trajetória de cada uma. Nas palavras de Badinter: "não existem dois modos de viver a maternidade, mas uma infinidade, o que impede de falar de um instinto baseado no determinismo biológico. Este depende estritamente da história pessoal e cultural de cada mulher" (2011, p. 70). Por outro lado, mesmo que "ninguém negue a imbricação entre natureza e cultura, nem a existência dos hormônios da maternagem, a impossibilidade de definir um comportamento materno próprio à espécie humana enfraquece a noção de instinto" (BADINTER, 2011, p. 70). Beauvoir (2016b), por sua vez, já no início das discussões feministas, é enfática ao afirmar que "não existe 'instinto materno': a palavra não se aplica em nenhum caso à espécie humana. A atitude da mãe é definida pelo conjunto de sua situação e pela maneira por que a assume" (p. 312).

Durante muito tempo, o discurso médico - que possui muita força na vida em sociedade - ancorou-se em postulados fisiológicos para se determinar a existência de hormônios capazes de definir as ações maternas, validando, dessa maneira, a ideia de instinto feminino reguladores de práticas e comportamentos pré e pós o nascimento da criança. Todavia, com o avanço da ciência e as preocupações médicas em derredor da figura materna, o que, consequentemente, se desdobrou em especialidades como a obstetrícia e a pediatria, tal entendimento vai aos poucos se transformando. Inúmeros estudos demonstram que os hormônios ocitocina e a prolactina (BADINTER, 1985; 2011; IACONELLI, 2015) são potencializadores da relação entre mães e filhos, porém as sensações provocadas por esses hormônios não são, necessariamente, o motor do instinto materno tão defendido em séculos anteriores; tampouco a ausência das sensações daí decorrentes implicam patologia feminina. Leite (2019) informa que "a ocitocina é liberada também no sexo e em outras situações de conexão humana” (p. 51), fato que nos leva a inferir que a simples ação liberatória de tais hormônios não é condição suficiente para definir o instinto materno. Apenas ratifica a tese de que

2 Menção à frase utilizada por Elisabeth Badinter em seção na obra $O$ conflito: a mulher e a mãe, publicado no Brasil pela Editora Record (2011).

3 O termo "maternagem" tem sido utilizado para se referir aos cuidados que "boas mães" dispensariam a seus filhos, ou seja, esforços dotados de afeto e zelo para com a criança, independentemente de ligação biológica. De acordo com a psicanalista Nancy Chodorow, é possível afirmar "que um homem 'maternou' a criança se ele foi a principal pessoa a cuidar dela, ou se está agindo de maneira a alimentá-la e amparála. Mas nunca poderíamos falar de uma mulher 'paternar' um filho" (2002, p. 27), entendimento que ressalta a importância e incumbência exclusivamente feminina no desenvolvimento da criança. 
se tratam de substâncias potencializadoras da intensidade da relação do par mãefilho/a.

Se, conforme nos apresenta Iaconelli (2015), a partir dos estudos freudianos, vislumbrou-se que "o bebê seria o objeto que comutaria a falta na mulher, espécie de consolo privilegiado diante da irreparável inveja do pênis" (IACONELLI, 2015, p. 130), há que se mencionar as contribuições de Margareth Hilferding, primeira mulher a ingressar na Sociedade Psicanalítica de Viena, liderada por Freud. A psicanalista supõe que seja "por meio da interação física entre a mãe e o bebê que é suscitado o amor materno" (HILFERDING, 1991, p. 90), sendo que o primeiro filho apresentaria função de destaque neste comportamento, posto que possibilitasse o desenvolvimento afetivo "pelo contato físico com a criança, através do cuidado, da amamentação". Enquanto que nos próximos, “o amor materno [seja] talvez inato no sentido de que ele surge sem problemas, pela lembrança dos cuidados ao primeiro filho" (HILFERDING, 1991, p. 91). Seja como for, não cabe aqui entrar nesse mérito ou questionar as indubitáveis contribuições psicanalíticas para a compreensão do fenômeno materno. Para tanto, seriam necessários estudos profundos acerca da teoria freudiana e posteriores neste campo, porém reduzir o aceite da maternidade simplesmente pela necessidade compensatória fálica não nos parece adequado. De que forma poderíamos, então, classificar as mães não biológicas? Seriam elas menos mães do que as que geraram, mas que abriram mão dos cuidados com a prole? No caso do romance em debate, seria a mãe adotiva de Maike menos mãe que Anna, justamente quem a abandonou no parque recém-nascida? Nesses casos, conforme expõe Kamers (2006), é imprescindível fazer distinções entre a mãe biológica e a função materna, porquanto seja recorrente, e insuficiente, buscar na primeira as ações funcionais da segunda.

Se as mulheres que abrem mão da maternidade para realizarem-se em outras frentes poderiam ser classificadas como deficitárias enquanto mulheres, Badinter (1985) chama a atenção para o fato de que essas são "demasiado numerosas para serem classificadas como exceções patológicas" (BADINTER, 1985, p. 346). De uma forma ou de outra, "não há comportamento materno suficientemente unificado para que se possa falar de instinto materno ou de atitude materna 'em si"' (BADINTER, 1985, p. 346), mas antes uma pluralidade identitária que constitui a ideia macro de maternidade.

Ao partirmos do pressuposto de que a maternagem estabelece-se do contato com o outro e não de razões estritamente biológicas, fica evidente que a relação estabelecida entre Anna e sua mãe, na casa de dona Clotilde, reverbera na forma como a atriz evita a filha desde a concepção. Recusar abertamente o vínculo com a doméstica é determinante para a forma como enxerga tanto sua gestação quanto sua relação com a criança após o parto, isso porque "as mulheres, como mães, produzem filhas com capacidades de maternar e o desejo de maternar. Essas capacidades e necessidades acham-se embutidas no próprio relacionamento mãe-filha e surgem dele" (CHODOROW, 2002, p. 22). Anna salienta essa maneira de agir quando adota outra perspectiva da relação com a mãe "evita[ndo] abordar, disse apenas, meu pai eu 
não conheci, morreu antes de eu nascer, minha mãe mora noutra cidade, no interior de Minas, mentiu" (SAAVEDRA, 2018, p. 26).

Estés (2018) comunga do mesmo entendimento acerca da importância da relação entre mães e filhas. De acordo com a psicóloga "a mãe precisa receber a atenção materna para dar atenção à sua própria prole” (p. 207), pois, por mais que haja o contato durante a gestação e, posteriormente, nos primeiros momentos da vida da criança, "ela simplesmente não se transforma de repente numa mãe temporal e completa por si mesmo" (ESTÉS, 2018, p. 207). Este conhecimento, no passado, era fulcral e determinante para o sucesso da maternidade. Era na figura da avó, das anciãs e até mesmo de vizinhas mais experientes que a jovem mãe - ou, na denominação de Estés (2018) como 'mãe-criança' - era estimulada a exercer suas habilidades maternas. Todavia, com o avanço da medicina essas figuras cada vez mais escassearam e foram substituídas pela autoridade médica que passa a determinar o comportamento materno correto.

Em se tratando de Anna, é possível cogitar que sua forma de maternar seja determinada, também, pela ausência do contato com a mãe. Com efeito, a atriz acompanhou todo o sofrimento da mãe na casa de dona Clotilde, sendo obrigada a servir aos patrões e a abrir mão de si e da filha; certamente essa imagem de maternidade influenciou em sua compreensão acerca da sua situação. Ademais, vê-se ainda o corte abrupto na transmissão de conhecimentos e, certamente, das formas de maternagens na linhagem familiar quando a própria empregada doméstica é reduzida à filha que carrega, em uma espécie de receptáculo desprovida de qualquer subjetividade. Não nos parece óbvio que em outro cenário a atriz agiria de outra forma em relação à filha, pois assim incorreríamos no equívoco de pré-determinar uma decisão sua de ir ao encontro do ideário materno, porém parece-nos possível entrever que a relação com a mãe - ou a falta dela - reflete-se na sua com a recém-nascida. Nesse caso, parece bem viável afirmar que o constructo cultural da maternidade foi deficitário na sua trajetória, já que sua mãe fora impedida de materná-la conforme as tradições de sua família, contando apenas com o espectro da Avó a orientá-la.

Entretanto, parece-nos razoável questionar se o contato com a criança é condição necessária para desenvolver o amor materno. No século XVIII, sobretudo na França, a contratação das amas de leite era regulamentada, de modo que as crianças, logo após o parto, eram separadas das mães e postas sob a tutela dessas mulheres que, comumente, deixavam de cuidar dos próprios filhos para conseguir algum dinheiro amamentando e cuidando das crianças cujos pais possuíam melhores condições econômicas. Nesse cenário, "amamentar o próprio filho equivalia a confessar que não se pertencia à melhor sociedade" (BADINTER, 1985, p. 96), aspecto que tende mais a evidenciar o atendimento às necessidades sociais que biológicas, ou, em outras palavras, mostra que a preocupação com o status familiar sobrepunha-se à preocupação com a criança. Logo, é a partir do valor que a criança adquire que se modifica a visão da maternidade e do cuidado infantil. As três formas de abandono (a entrega à ama, governanta e preceptor, e o internato) observadas pela filósofa francesa em seu levantamento histórico poriam por terra o incontestável amor materno que 
nos séculos seguintes aprisionariam as mulheres, elucidando que a forma como a maternidade é enxergada e exercida nada mais é que o produto da economia e do momento histórico observado (BADINTER, 1985).

A relação entre a atriz e sua mãe, de forma inversa ao que o ideário social postula, é marcada pela incompreensão e incerteza, ou, como o narrador apresenta: "um nó cego, não era um laço" (SAAVEDRA, 2018, p. 28). Ainda que procure deixar a mãe em segundo plano, Anna, em sua estada na Alemanha, "surpreendeu-se lembrando muito da mãe com seu uniforme de empregada espanando bibelôs, limpando os banheiros da casa de dona Clotilde, seu corpo escuro e seco, sua ignorância, a mãe, para quem Paris era tão distante quanto a Lua" (SAAVEDRA, 2018, p. 45). É perceptível que somente pela ausência e por estar em outro país, em situação semelhante, isto é, longe dos seus e à revelia dos seus anseios, a atriz direciona sua atenção para mãe e é capaz de reavaliar sua conduta e o rumo que sua vida tomou. Daí a importância dos deslocamentos espaciais para a composição identitária da personagem ou sua percepção de si.

Uma vez mais podemos vislumbrar a interferência de dona Clotilde no processo relacional do par mãe-filha, isto porque ao mesmo tempo em que a primeira, forçosa e inconscientemente, abdica de sua maternagem pelo conforto que a empregadora pode oferecer à afilhada, a segunda incomoda-se com a resignação da mãe em abrir mão do controle da vida de ambas. Aquela "mãe que ela tentava esquecer”, porém, é a mesma a quem suplica, ao se enxergar sozinha e grávida em outro país, "quase inaudível, mesmo que a mãe fosse apenas uma pessoa que a tinha parido e que ela chamava de mãe” (SAAVEDRA, 2018, p. 54).

É possível que a relação de Anna com a mãe reflita na sua decisão de não ser mãe. Ora, se desde a infância condicionamos as meninas a optarem pela maternidade e, dessa maneira, perpetuamos o movimento cíclico prisional do sexo feminino apresentado por Beauvoir (2016a; 2016b), é evidente que a atriz, ao fazer parte da quebra deste movimento, ou seja, de não estabelecer o vínculo afetivo com a mãe, não sinta desejo em gerar outra vida. Entretanto, afirmar que somente a relação mãe-filha seja o mote para a gestação seria simplificar as identidades femininas e, novamente, condicioná-las a manterem-se reféns de sua condição biológica reprodutiva. O que nos chama a atenção é, primordialmente, o fato de que a experiência negativa com a mãe e, por consequência, com dona Clotilde pode ter acentuado, porém não determinado, a recusa da gravidez e do contato com a filha recém-nascida.

No excerto "Anna só pensava em seu corpo em pedaços e nesse algo que se agarrava a ela, essa coisa que grudava, precisava com urgência arrancá-la dali, mas suspeitava que não teria coragem, ainda mais aos quatro meses, ela não conseguiria" (SAAVEDRA, 2018, p. 54), é pungente o misto de sentimentos que permeiam a personagem em relação à gestação. Diferentemente do constructo social que apregoa que as mulheres desde a concepção já se sentem mães, Anna "não queria esse filho, disse com todas as letras, isso que está aqui dentro não é meu filho, é qualquer coisa, mas não é meu, ele a olhou como se ela fosse um monstro, não fale assim" (SAAVEDRA, 2018, p. 55). A trajetória da personagem, como bem demonstram esses 
fragmentos, põe a nu o ideário social que demoniza a mulher que se recusa a doarse com abnegação para que a vida faça-se nela. É a figura masculina, neste contexto, que atua como porta-voz do corolário social, para quem a negação da maternidade, vista com horror e aversão, não é uma possibilidade para a mulher "normal". Assim é que os autoquestionamentos de Anna do tipo "Havia um corpo dentro do meu corpo, algo humano?” (SAAVEDRA, 2018, p. 182), embora apresente-se como a simples verbalização da consciência da personagem, soa monstruoso. Trata-se de iluminar um modo de pensar e sentir que mesmo silenciado pelos pilares patriarcais que ainda sustentam a sociedade contemporânea não deixa de existir.

Negar a gravidez e, portanto, a maternidade para a aspirante a atriz é apenas recusar uma identidade possível, mas que não a representa. Trata-se de mais um papel social passível de ser dispensado pelas mulheres. A primeira parte do romance, quando focalizada em Anna e Avó, é narrada em terceira pessoa por um narrador onisciente, de modo que é significativo o fato de, na segunda, quando o foco recai na trajetória de Anna, passar a ser narrado em primeira pessoa por ela própria. No limite, podemos interpretar que o gesto de ser representada como quem é capaz de assumir a palavra implica uma espécie de metáfora para o controle que ela exercerá sobre sua vida. Ao passo que para a empregada de dona Clotilde, tomar o discurso e contar sua história é uma possibilidade que feriria a verossimilhança do romance. Precisar da voz alheia para se fazer conhecer é coerente com o silenciamento a que é submetida, não só quando engravida do filho da patroa, mas desde antes quando a mãe a expulsa de casa, aos catorze anos, porque "ela já tinha idade para se virar sozinha” (SAAVEDRA, 2018, p. 131), e ela só pode contar com o choro para expressar seu medo. No caso de Anna, assim, a recusa da maternidade denota que a mesma é capaz de tomar para si as rédeas da própria vida, não se preocupando com a opinião alheia. Se, a contragosto, aquela "coisa crescia em silêncio dentro da sua barriga" (SAAVEDRA, 2018, p. 55, grifo nosso) e veio ao mundo contrariando seus desejos, o ato de abandono evidencia que ,mesmo dentro de um contexto opressor, a personagem não se deixa dominar e é capaz de fazer valer suas escolhas.

É nesta direção que aponta o título do romance. Ainda que a todo instante a recusa à maternidade, perante a sociedade, seja questionada e associada a desvios comportamentais, é necessário problematizar, afinal o gesto de não querer ser mãe ou de se arrepender de o ser não pode ser condenado de antemão. São justamente expedientes como o literário, por exemplo, que contribuem para as necessárias mudanças de mentalidades. Contudo as armas disponíveis são ainda "sonolentas". Isso implica dizer que problematizar temas naturalizados na sociedade, como é o caso da maternidade, não é uma tarefa fácil. Face ao poder dos valores hegemonicamente construídos ao longo do patriarcado, os desejos femininos são passíveis de impugnação. Mas, se o armamento de que dispõem as mulheres são débeis quando comparados àqueles cristalizados ao longo de séculos de dominação masculina, são imprescindíveis para germinar a dúvida sobre os papéis a elas impostos como se fossem inatos à sua natureza. 
A indagação de Anna, quando tem sua aparência enaltecida apesar da gravidez, põe em xeque a beleza incondicional vislumbrada à priori no corpo de uma mulher grávida. O questionamento "Linda, Heiner?, ninguém é linda assim, linda, obrigada a carregar no corpo outro ser humano" (SAAVEDRA, 2018, p. 55, grifo nosso) e o uso do verbo "obrigada" em destaque elucidam a forma como a personagem (e tantas mulheres) vê a gestação, isto é, uma obrigação para com o outro e não consigo mesma. Sendo a capacidade de gerar a única prerrogativa exclusivamente feminina, é no mínimo curioso o fato de as mulheres serem aprisionadas ao que, a princípio, seria um privilégio. Tal privilégio não só as condenam a ter o próprio corpo posto a serviço do outro, às vezes à revelia, mas se tornarem compulsoriamente responsáveis por esse outro, em um movimento que pressupõe a anulação de si. Da perspectiva de Beauvoir (2016b), a mulher "não fez realmente o filho: ele se fez nela; sua carne só engendra carne: ela é incapaz de fundar uma existência, que se terá de fundar ela mesma” (p. 296).

Diz o senso comum que o corpo materno é o primeiro lar do ser humano. De fato, se nos pautarmos no viés da simbologia nos termos de Chevalier \& Gheerbrandt (2015), a casa remete ao "feminino, com o sentido de refúgio, de mãe, de proteção, de seio maternal” (p. 197). Também para Bachelard, na sua poética do espaço (2003), a casa configura-se como lugar onde a vida se cria, numa extensão simbólica do papel da mãe. Da perspectiva que nos move nessas considerações, cabe problematizar a legitimidade de considerar o corpo materno como lar ou hospedaria, sobretudo em casos de gravidezes indesejadas.

No romance de Saavedra, Anna, recorrentemente, verbaliza sua insatisfação em ter outro ser humano no ventre, de modo que podemos inferir que, do ponto de vista psicológico, este primeiro lar não é tão acolhedor assim, acarretando conflitos tanto nela quanto na criança. A negação da gravidez implica também a negação da identidade materna que a protagonista não deseja tomar para si. No fragmento "Quando soube que estava grávida, fingi que não era comigo, como se a notícia me dividisse em duas" (SAAVEDRA, 2018, p. 182), o/a leitor/a vislumbra a personagem dividida entre dois "eus": um reconhecível/familiar e um outro que lhe soa estranho, invasivo, impositivo. Duas identidades incompatíveis.

Motivo de controvérsias morais e religiosas - quando deveria ser uma questão de saúde pública - o aborto é descartado pela personagem devido ao estágio avançado da gravidez. Além disso, ela não contaria com o apoio da figura masculina envolvida e, se estivesse no Brasil, também não teria o suporte de políticas públicas que lhe assegurassem esse direito. Quando decide levar adiante a gestação para, depois, encaminhar a criança para adoção, o marido assume a voz do senso comum e sanciona negativamente sua decisão como uma afronta irremediável aos valores regulatórios da sociedade em que se inserem: "você está louca, Heiner se enfureceu, pela primeira vez perdeu o ar blasé que o acompanhava, parecia outra pessoa, você não vai dar o meu filho, afinal, que tipo de pessoa é você?" (SAAVEDRA, 2018, p. 55). Trata-se de ecoar uma vez mais a voz masculina reverberando o constructo social materno porquanto não considere o abandono de um filho, tampouco a falta de abnegação de 
si como atitudes femininas. A represália do marido nada mais é que a verbalização das malhas de poder que impelem a mulher a manter-se refém de um papel social prédeterminado pela sua condição biológica. No tratamento dispensado pelo marido, enxergamos como as identidades femininas são culturalmente pré-determinadas, de modo que qualquer alteração de rota passa a ser considerada loucura: "eu carrego essa criança no meu corpo contra a minha vontade, Heiner a olhava como se ela fosse louca" (SAAVEDRA, 2018, p. 57).

Proibido no Brasil, o aborto mata uma mulher a cada dois dias ${ }^{4}$ em procedimentos clandestinos. No século passado, a Igreja Católica priorizava a vida do recém-nascido em detrimento da vida da mãe ${ }^{5}$, visto que essas, por serem batizadas poderiam alcançar a salvação, enquanto que o feto estaria fadado ao limbo como bem pontuou Beauvoir (2016b) na primeira metade do século XX. Além disso, argumentava a filósofa, "a sociedade tão encarniçada na defesa dos direitos do embrião se desinteressa da criança a partir do seu nascimento” (p. 28o), apontando para o falso moralismo que alicerçava os preceitos religiosos. Ao negar às mulheres o direito ao aborto, a sociedade nega-lhes, consequentemente, o controle do próprio corpo, o direito de escolher se desejam de fato tornarem-se mães, este papel social que secularmente as aprisionam junto à casa e ao/à filho/a e limita sua participação na vida pública.

Vencida a etapa da "decisão" de ser ou não ser mãe, outra grande preocupação do público feminino em relação à maternidade diz respeito ao parto. Como esclarece Leite (2019), inúmeras mulheres, nas primeiras consultas médicas do período prénatal, já buscam a anuência do/a obstetra para o procedimento cirúrgico parturial a fim de driblarem as dores herdadas da desobediência de Eva, implacavelmente sancionada com a sentença bíblica "entre dores, você dará à luz seus filhos" (BÍBLIA, 1998, p. 17). Serão, todavia, as mulheres realmente livres para escolherem a melhor forma de dar à luz? Ou, estando elas pautadas no dogma religioso em consonância com o discurso médico, são induzidas a seguir o consenso geral de que a cesárea é a melhor opção para a mãe e para a criança? Para Iaconelli (2015), também nessa seara, a autonomia feminina é questionável: com a hospitalização da maternidade, o corpo feminino parece ter se tornado comercializável, assim como o da criança que é afastada do ambiente doméstico assistido pela família. As mulheres, nesse sentido, cada vez mais parecem perder a autonomia sobre suas gestações.

No romance saavedreano, a representação do parto é marcada pela punição feminina, de modo que o desejo da parturiente é desconsiderado. Enquanto dava à luz de forma natural, Anna tinha "a sensação de que o corpo estava se partindo em pedaços, implorou para que fizessem uma cesárea, ou ao menos algum tipo de

4 Maiores informações podem ser obtidas pelo site <http://www.cofen.gov.br/uma-mulher-morre-acada-2-dias-por-causa-do-aborto-inseguro-diz-ministerio-da-saude_64714.html>. Acesso em: 11 jul. 2020.

5 Atualmente, de acordo com o Ministério da Saúde e com o Código Civil, no artigo 128, quando trata das permissões para o aborto, em caso de risco de morte para ambos, mãe e criança, o corpo médico deverá priorizar a vida da primeira. 
anestesia, a enfermeira a olhou com desprezo" (SAAVEDRA, 2018, p. 57). É evidente que os olhos da profissional de saúde são metonímia para a sociedade que enxerga nas dores do parto a feminilização da maternidade e a punição para o ato sexual aí presumido. Não bastasse o discurso religioso que, como postula Muraro (2002), passa a significar controle e autoritarismo, dando origem às práticas de dominação masculina, não é difícil encontrarmos mulheres deleitando-se com as dores durante o parto como forma de sanção pelo gozo feminino, sem se darem conta de que o clitóris é "o único órgão humano que tem como exclusiva finalidade servir ao prazer das mulheres, enquanto ao pênis [...] falta o refinamento da especialização" (SILVEIRA, 2002, p. 357). Neste cenário, além da perpetuação do ideário segundo o qual a mulher deve se restringir a propiciar prazer e não senti-lo, emerge a categoria da violência obstétrica, dado que não é somente a violência física que se classifica como tal. Toda forma de coação, abusos físicos ou sexuais, além de comportamentos discriminatórios e/ou não atendimentos das normas profissionais, são práticas violentas que precisam ser denunciadas por colocarem as mulheres em condições degradantes física e emocionalmente.

Para além das modalidades do parto e suas significações, a questão da amamentação também vem sendo questionada no âmbito dos discursos contra hegemônicos. Se historicamente vem-se cogitando que é pela amamentação que as relações entre mães e filhos/as se estreitam, fazendo, dessa forma, aflorar o instinto maternal (HILFERDING, 1991), há que se considerar, por outro lado, que tal raciocínio tende a invalidar o amor daquelas mães que se encontram impossibilitadas de amamentar, seja pela escassez de leite, seja por outros problemas de origem fisiológica ou psíquica, sem contar o caso das mães adotivas que não tendo parido o filho raramente são capazes de amamentá-lo. Novamente nos deparamos com a ambivalência das regulações das práticas afins à maternidade, cujas nuances extrapolam as predeterminações sociais. Mas, mais do que simplesmente chamarmos a atenção para a impossibilidade de se padronizar ou naturalizar o amor materno, queremos colocar luz na prática da amamentação como constructo social. Durante muito tempo, a amamentação foi vista como um gesto vulgar e repugnante que afastava a figura masculina do leito conjugal (BADINTER, 1985), evidenciando que mais importantes que o estreitamento dos laços entre mães e filhos/as, são os interesses da coletividade masculinista que, nesse caso, coincide com a prática do confinamento das mulheres nos muros das casas, quando não dos quartos, a fim de que possam cumprir com os deveres que a condição de mãe lhes impõem. É nessa ordem de ideias que o próprio seio feminino, como bem salienta Badinter (2011), é tomado unicamente como instrumento de amamentação, cumpre unicamente sua função de alimentar o/a bebê e, portanto, pertence ao/à bebê e não à mulher. À mulher cabe aceitar seu papel altruísta de doar-se para que a vida faça-se nela e seja por ela nutrida. Se, como assevera Beauvoir (2016a), é pela libertação da obrigatoriedade da reprodução e da participação na produção que sua condição evolui, a amamentação é utilizada para impingir-lhes o sentimento de culpa, ao mesmo tempo em que dificulta sua inserção e permanência nos meios de produção. 
Ao perscrutarmos a trajetória da Anna-mãe, constatamos que a relação afetiva com a filha - supostamente derivada do gesto de amamentar - não se concretiza, ela só consegue enxergar na criança a mamífera que todo ser humano é, de forma a restringir sua maternidade ao aleitamento: "então isso é ser mãe, pensou, um bicho sugando as tetas de um outro bicho, se alimentando de um outro bicho, e ela olhava para o bebê e olhava para Heiner e não sentia nada" (SAAVEDRA, 2018, p. 58). Sua concepção de maternidade é pautada unicamente pelo atendimento às necessidades básicas da filha, como a alimentação, por exemplo, e ainda assim realiza tais atividades com desgosto. Um desgosto que ela já antevia: "eu não posso ter esse filho, disse, não quero, de jeito nenhum, e foi quando a médica explicou que com a gravidez já tão avançada não era mais possível nem mesmo uma curetagem, no seu caso tratavase já de uma cirurgia, porque aos quatro meses o feto..." (SAAVEDRA, 2018, p. 53). Tendo a maternidade sido santificada na figura de Virgem Maria - o símbolo máximo da doação altruísta de si, alicerce do cristianismo - recusá-la depois de concretizada na concepção implicaria horrorizar a sociedade e ter de arcar com o ônus.

O processo de desconstrução da naturalização do amor materno tal como é concebido hoje não pode desconsiderar o fato de, no século XVII, a transferência dos cuidados com as crianças abastadas a terceiros era uma questão de status social. Após o nascimento, eram as amas de leite que se incumbiam delas até que bem crescidas pudessem retornar para a casa e para suas mães que mal as conheciam. $\mathrm{O}$ constructo social contemporâneo, todavia, não hesita em condenar a mãe que, como Anna, ousar não reconhecer no/a filho/a uma parte de si, a melhor parte, diga-se, mas apenas "isso, um bicho [...] não conseguia compreender como aquilo havia saído de dentro dela, como era possível um absurdo desses, que um ser humano saísse de dentro de outro ser humano, quem havia inventado algo tão inverossímil assim?" (SAAVEDRA, 2018, p. 58).

Criada por uma mãe ausente e por uma madrinha que, embora a aceitasse como afilhada, renegava-a como neta, Anna também se sente rejeitada por todos ao seu redor após o nascimento da filha: "ninguém se lembrava dela, ninguém vinha lhe perguntar como ela estava se sentindo. Ninguém lhe perguntava do horror, das noites sem dormir, do bebê que só fazia mamar, até que ela, quase louca, e o bebê ali pendurado, sugando tudo o que pudesse" (SAAVEDRA, 2018, p. 59). A exaustão da personagem vislumbrada nesse fragmento em relação às funções maternas desnuda ao/a leitor/a o fato de a romantização da maternidade esconder um sem número de dificuldades a serem enfrentadas pelas mulheres. Mesmo as mães adaptadas às exigências que o papel requer são, não raro, atormentadas pela culpa, a culpa pela possibilidade de não estar desempenhando eficazmente seu papel, a culpa pelas pequenas falhas na avaliação das necessidades do/a filho/a, a culpa antecipada pelas falhas que poderá vir a cometer num processo que não admite falhas e que, portanto, desumaniza as mulheres-mães. Parece, dessa forma, que ser mãe é inevitavelmente sentir-se culpada; mesmo quando tudo parece estar a contento das exigências culturais, a mãe está sob o olhar desconfiado do mundo, "afinal de contas, se você não sente culpa por algo que toda boa mãe sente, certamente há algo errado no seu 
modelo de maternidade ou, pior ainda, na sua relação com seu filho" (LEITE, 2019, p. $62)$.

A indiferença da personagem em relação à filha tira o/a leitor/a da sua zona de conforto e o/a convida à reflexão acerca da naturalidade do amor materno como algo incondicional, livre de qualquer ruído ou interferência, inerente a todas as mulheres: "e ficou ali, olhando para o bebê, que enfim havia parado de chorar, não sentia nada. Nem carinho, nem raiva, muito menos amor" (SAAVEDRA, 2018, p. 6o). Caberia à personagem questionar se acaso ela é uma mulher? Como ser mulher se ao tornar-se mãe ela não é capaz de amar incondicionalmente a filha? O que seria Anna, então? É possível especular que a indiferença da personagem em relação à filha seria um sintoma da depressão pós-parto que acomete muitas mulheres ao redor do mundo, entretanto, condicionar suas escolhas a uma patologia seria aceitar a "verdade" de que o comportamento desviante da norma pré-estabelecida, nesse caso, do amor incondicional das mães aos/às filhos/as desde a gestação, não possa existir. O romance de Saavedra, nesse sentido, promove a representação e, portanto, a problematização de identidades femininas que desromantizam a maternidade e colocam em evidência pontos de vista femininos que contrariam os padrões estabelecidos, mas que são perfeitamente plausíveis. O desabafo de Anna, destacado a seguir, avança nessa direção e explicita que a desassociação da identidade materna do ser feminino, embora gere culpa dada a força do habitus (BORDIEU, 2015), não pode ser tomada como absurda: "Não, eu não sou um monstro, eu sou só uma pessoa. (Silêncio) Mas, por algum motivo, a ideia do monstro me ronda e insiste e estende suas garras sobre mim" (SAAVEDRA, 2018, p. 188).

O mesmo habitus que desencadeia o sentimento de culpa da protagonista é o que condiciona as meninas desde a infância a abraçarem a maternidade como único destino das mulheres. No fragmento "Eu pari um amontoado de células que costumamos chamar 'outro ser humano', e, ao fazê-lo, apenas reproduzi o gesto de todas as mulheres da minha linhagem, minha mãe, minha avó, minha bisavó, minha tataravó, minha tataratataravó" (SAAVEDRA, 2018, p. 175), a protagonista convida o/a leitor/a para esse debate.

A sua autopercepção da dificuldade em "explicar que eu não era mãe de um corpo só porque ele saíra de dentro de mim [dela]" (SAAVEDRA, 2018, p. 177), funciona como mote do processo de desnaturalização da maternidade e do amor materno que o romance parece propor. Pelo menos do ponto de vista da protagonista, tais processos não só não lhe parecem naturais, mas lhe soam totalmente incompreensíveis, de modo que, na prática, ela desatrela a maternagem do período gestacional, fazendo reverberar o postulado de Iaconelli (2015) segundo o qual o desejo da gestação também ausente na trajetória de Anna - pode não implicar consequentemente o desejo de maternar:

E eu fiquei ali, desorientada, exausta, diante daquele outro ser humano que chorava e mamava e dormia e soltava secreções por todos os orifícios do corpo. E era também através de um desses 
orifícios do corpo chamado boca que o outro ser humano sugava a ponta do meu peito, que nada mais era do que também um pedaço de carne com ínfimos orifícios, dos quais saía sangue que, desprovido dos glóbulos vermelhos, chama-se leite. Eu fiz tudo isso: festei e pari e vesti e alimentei um pedaço de carne, chamado também de 'outro ser humano', e limpei suas secreções e excrementos e o coloquei num berço a salvo de intempéries e predadores, eu fiz tudo isso que minha mãe e minha avó e minha bisavó e minha tataravó e minha taratataravó haviam feito, mas nem por isso tornei-me mãe (SAAVEDRA, 2018, p. 176).

A fala de Anna dá voz a um sem número de mulheres que mesmo hoje vivem sob o jugo de uma sociedade que as impelem à maternidade como forma de se tornarem mulheres em toda a plenitude do termo. Além de invalidar as outras identidades femininas, obrigá-las a experienciar algo contra a sua vontade, como é o caso da personagem em questão, além de acarretar severas consequências para a própria mulher pode pôr em risco à vida do/a bebê. A atriz, ainda que tenha dado à luz e amamentado - experiências que poderiam classificá-la como mãe - é categórica em afirmar que "aquela filha" não era mais dela, "nunca fora" (SAAVEDRA, 2018, p. 177). Trata-se de a escritora representar pela própria perspectiva feminina a viabilidade do fato de a experiência materna poder, sim, ser acompanhada de arrependimento e que desconsiderá-lo ou atrelá-lo a desvios patológicos ou ainda torná-lo mote para retaliações ideológicas às mulheres que não se identificam com a identidade materna só sinaliza "que é perigoso que as mulheres olhem para trás e avaliem a transição para a maternidade como algo que não vale a pena" (DONATH, 2017, p. 225-6).

O movimento circular que permeia a trajetória das personagens femininas do romance, espécie de rota que as mulheres são culturalmente incentivadas a repetir, é, em certa medida, interrompido por Anna. Embora ela tenha inicialmente realizado, ainda que a contragosto, todas as atividades maternas que suas antecessoras realizaram, ela se nega a continuar representando o papel de mãe, um papel que não a representa. A transmissão de conhecimentos que envolvem e perpetuam o comportamento feminino no que tange à maternidade só se concretiza até certo ponto. Ela se dá conta de que a repetição dos atos não a torna igual às demais. A consciência de que as mulheres sempre estiveram condicionadas a repetirem padrões, enquanto aos homens sempre foi permitido se reinventar, a torna capaz de empreender a ruptura do ciclo.

Exausta e sem ajuda do marido, Anna só consegue pensar em livrar-se da filha. Neste ato desesperado visualizamos o pedido de ajuda de tantas mulheres. Ao assumir ser uma "mulher muito jovem [que] abandona o seu bebê de poucos meses num parque [...] uma mulher abandona o seu bebê. (Pausa) Essa mulher sou eu" (SAAVEDRA, 2018, p. 169, grifo da autora), a representação feminina possibilita desatrelar a imagem pejorativa da recusa materna de tantas outras mulheres. 
Contudo, ainda que seja uma ação revolucionária, Anna não deixa de se questionar: "Que monstro é esse que pare um filho e o abandona?" (SAAVEDRA, 2018, p. 171). A reflexão da personagem sugere que, mesmo agindo de acordo com sua própria subjetividade, as amarras sociais insistem em se fazer presentes e associar seu desejo de não vivenciar a maternidade à maldade ou à falta de humanidade. Mais do que um papel social, é preciso encarar a maternidade "como parte de um espectro de experiências humanas, em vez de um vínculo unilateral” (DONATH, 2017, p. 222) e, como toda experiência, o indivíduo está sujeito a arrepender-se e/ou voltar atrás. Com efeito, o arrependimento é, quase sempre, sobre o que não foi feito diante da possibilidade de se fazer, logo "arrepender-se de ser mãe indica que há na verdade caminhos que a sociedade proíbe as mulheres de tomarem, eliminando a priori vias alternativas como a não maternidade" (DONATH, 2017, p. 13).

Não se trata, todavia, de induzir ou incentivar o abandono de filhos/as a condições degradantes que possam colocá-los/as em risco de morte. Antes, o romance propõe a reflexão sobre as motivações que levam, por exemplo, a sociedade a considerar o abandono paterno como menos pecaminoso do que o materno. Mesmo aqueles pais que se mostram participativos nos cuidados com a prole - o que não é o caso de Heiner, posto que "tinha muitíssimo trabalho com o novo filme" (SAAVEDRA, 2018, p. 59) - o fazem com menos comprometimento em relação às mães, mas são bem mais aplaudidos e reconhecidos pela mídia ${ }^{6}$ que as mulheres, o que, infelizmente, implica considerar que "é preciso muito pouco para ser considerado um paizão. E é preciso muito pouco para ser considerada uma péssima mãe" (LEITE, 2019, p. 102). Por outro lado, creditar a recusa da maternidade unicamente à falta de cooperação do cônjuge ou à falta de condições sociais é reforçar estereótipos e identidades dos quais as mulheres buscam se distanciar, sinalizando que optar pela (não) maternidade implica a manifestação de um desejo, uma escolha que a mulher precisa ter a liberdade de fazer.

Para além do binarismo mãe versus não mães, Donath (2017) problematiza situações de mulheres que se tornaram mães e arrependeram-se da experiência. Tal arrependimento, todavia, nada tem a ver com o amor que essas mulheres sentem por seus/suas filhos/as, apenas diz respeito ao sentimento em relação ao papel social que tiveram que assumir. Se, como assevera a socióloga, o amor materno é uma invenção ocidental em decorrência do "surgimento da família nuclear e a separação entre as esferas 'privada' e 'pública', assim como resultado de mudanças demográficas e a diminuição das taxas de mortalidade infantil” (2017, p. 128), por que deslegitimarmos a feminilidade das mulheres que não se sentem confortáveis em transmitir/fazer parte desse amor? Por que poderia causar incômodo às gerações anteriores o comportamento de Anna? É incontestável que esse aspecto "se tornou uma forma de opressão, já

6 Destacamos a matéria publicada pelo site O Fuxico, sobre o ator Rodrigo Hilbert, em que é apresentado motivos para classificá-lo como um grande homem, ainda que o próprio ator rejeite o título. Chamanos a atenção o fato de a grande maioria das atividades elencadas pelo site serem desempenhadas cotidianamente pelas mulheres sem criar alardes. A matéria completa pode ser lida em: < https://www. ofuxico.com.br/noticias-sobre-famosos/10-motivos-pra-concordar-que-rodrigo-hilbert-e-o-homaoda-porra/2017/o4/13-292028.html>. Acesso em: 26 jun. 2020. 
que estabelece os requisitos específicos que forjam o mundo emocional das mães e suas relações com seus filhos: elas devem sentir um amor incondicional pelos filhos" (DONATH, 2017, p. 129). No caso de Anna, mesmo que a personagem declare sentirse ambivalente perante a maternidade não exercida, não deixa de soar melancólica a sua purgação em público pelo abandono cometido. É intercalando os abandonos da filha e da mãe que a atriz vai costurando sua identidade materna ao tentar minimizar, por meio da imaginação ("Pouco depois alguém encontrou o bebê. Gosto de imaginar que foi assim, para que a história se torne suportável” (SAAVEDRA, 2018, p. 169)), seu sentimento de culpa. Dessa maneira, construir ilusoriamente aquilo que poderia ter sido no que concerne a sua relação com a filha, estabelece um paralelo para amenizar perante si mesma e, provavelmente, ao mundo o seu desvio da conduta esperada de todas as mulheres. O movimento cíclico, em outros momentos abordados no decorrer desses escritos, aparece novamente ao final da peça de Anna Marianni quando a mesma se recorda da mãe na canção de ninar que canta ao embalar nos braços o bebê que não quis. Tal gesto elucida a tradição passada de mãe para filha, numa teia de costumes que mantém as mulheres diacronicamente próximas da maternidade, de modo que romper com esse paradigma é sinônimo de anormalidade.

Se, por um lado, as representações tanto da avó paterna de Anna quanto da empregada doméstica assentam os pilares de uma maternidade e feminilidade no patriarcado, por outro é seguro afirmar que a atriz rompe com a relação esperada das mulheres no que diz respeito à procriação e cuidados com os/as filhos/as. Isso porque, abrir mão da maternidade, mesmo no século XXI, parece significar não ser uma mulher completa nos moldes patriarcais. A figura fantasmagórica da avó ancestral, por sua vez, mostra-se como a memória feminina dos ritos maternos porquanto seja o espírito da matriarca quem indica os cuidados da neta para com Anna. O espectro, então, funciona como essa ideia de naturalização cíclica que paira na sociedade tanto na condução da maternidade quanto na divisão de classes. Afinal, "tudo anda em círculos, mais cedo ou mais tarde, voltaremos ao ponto de partida" (SAAVEDRA, 2018, p. 262).

No romance saavedreano, a representação da maternidade, sobretudo a partir da trajetória de Anna, conforme discutimos em parágrafos anteriores, dá-se de forma a promover o questionamento do entendimento da mesma a partir da ideia de natureza feminina, de modo a lhe salientar o caráter de constructo social que, como tal, é passível de desconstrução. Por outro lado, as representações das avós (a mãe de Anna e a figura espectral, avó da mãe de Anna), ao mesmo tempo em que estão assentadas nos pilares patriarcais reforçando a ideia de natureza feminina, explicita outras variantes que afetam diretamente as formas de maternagens. $\mathrm{O}$ poder econômico e as relações de trabalho, no caso da empregada doméstica, são determinantes para que o exercício da maternidade pela personagem seja modificado abrindo, consequentemente, a possibilidade do afastamento entre ela e a filha. De toda forma, é a partir dos deslocamentos espaciais a que as personagens se submetem ou são submetidas no desenrolar da trama que vai se instituindo a representação de certa gradação no que diz respeito ao modo de as personagens conceberem a maternidade. Se na trajetória da Avó (figura espectral) visualizamos ritos ancestrais e 
uma forma de maternar que vai além das fronteiras da vida e da morte, na da sua neta (mãe de Anna), forçada a deixar o amparo da família para ganhar a vida, outra lógica se impõe: questões econômicas funcionam como argumentos para que permaneça passiva diante do afastamento da filha provocado pela ação de dona Clotilde (sua patroa e avó biológica da criança). Mas é com Anna, como demonstramos, que a perquirição e desconstrução da maternidade enquanto atributo inerente a todas as mulheres atinge o ápice, abrindo caminhos para a reavaliação de paradigmas que pré-determinam identidades femininas.

\section{Algumas considerações}

Não aceitar a maternidade como destino é recusar a feminilidade, ecoam as vozes do patriarcado. Seria a recusa capaz de inviabilizar as identidades femininas? Obviamente que não. Se nos parece natural falar sobre a - hipotética e ilusória equidade entre os gêneros, por que ainda perguntamos por que algumas mulheres não desejam ter filhos/as, ao invés de lhes perguntarmos os motivos que as levam a têlos/as? Por que é tão incômodo ouvir mulheres afirmarem que não desejam se casar e/ou ter filhos/as, ou, o que soa mais absurdo, que se arrependeram da maternidade?

Carola Saavedra, escritora que vem se destacando na seara literária brasileira, nesse seu último romance, não deixa de lado discussões como essas, caras ao contexto atual em que as práticas machistas são escamoteadas por detrás dos discursos da igualdade de gênero. A arte literária, nesse sentido, funciona como espaço privilegiado de debates a partir do qual a escritora faz ressoar a necessidade de ressignificação dos vínculos parentais pautados na objetificação das mulheres. A trajetória de Anna expõe fissuras no comportamento materno convencional, evidenciando as ambivalências de emoções que a experiência pode proporcionar às mulheres, mas, mais do que isso, explicita ao/à leitor/a como também podem ser legítimas as atitudes femininas pautadas na negação de tal experiência. É significativo, todavia, que mesmo tendo agido de forma consciente, não consegue se desvencilhar por completo da institucionalização da maternidade como destino de mulher. As armas de que dispunha para se levantar contra esse estado de coisas são "sonolentas", como tão bem assevera o título do romance. Embora o gesto de abandonar a menina tenha implicado, certamente, uma decisão pautada na sua verdade, na verdade de que não se sentia mãe dela, é relativizado, na segunda parte do romance, quando em seu solilóquio no teatro, a personagem apresenta (ou interpreta?) momentos de arrependimento. Decorre daí esse enfraquecimento das armas de que dispõem as mulheres na medida em que o ideário social e a culpa incutida secularmente na psique feminina, legitimados pela óptica dominante permanecem latentes. Parecenos axiomático que em uma hipotética necessidade de escolha entre a maternidade e o trabalho, a atriz escolheria o segundo campo de atuação, fato que por si só despertaria confrontamentos perante a família e a sociedade. É, provavelmente, no 
abandono da criança que acontece a maior ruptura dos paradigmas maternos, pois expõe o desejo feminino e o controle sobre suas vidas. De outra forma, ainda que se, à sua revelia, cumprisse as funções maternas de nutrição, cuidados e zelo, mesmo não gostando da filha, o simples fato de estar na companhia da menina a enquadraria no que se espera de uma boa mãe.

Diante dessas reflexões, parece-nos razoável conjecturar que o instinto materno nada mais é que uma construção sócio-histórica porquanto reproduza interesses maiores que não os estritamente decorrentes da relação entre mãe e filhos/as. Afirmar tratar-se de um atributo irremediavelmente associado à feminilidade não apenas limita a atuação das mulheres, como deslegitima e considera patológicos comportamentos desviantes da irracional naturalização do instinto. Dessa forma, ter em conta que as experiências provenientes do caráter reprodutivo feminino são ímpares e não dizem respeito às classificações hierárquicas - nas quais busca-se, equivocadamente, definir o melhor padrão de mulher - mostra a falácia em que está assentada a naturalização de comportamentos e emoções que pouco, ou nada, têm a ver com o sexo do indivíduo. Tomar como insana a atitude de Anna de abandonar a filha para que outros se incumbam dos cuidados demandados, os quais ela não se sente capaz de atender, sem considerar a força de sua vontade como argumento legítimo, implica reafirmar a tese do instinto feminino de maternidade, cristalizado ao longo da história da humanidade. Do mesmo modo que condenar a avó por permitir que dona Clotilde cuidasse e educasse Anna na infância, sem levar em consideração a situação social e econômica em que se encontrava, seria outorgar a todas as mulheres a obrigação de superar tudo pelos filhos, até mesmo aquilo sobre o que elas não têm controle, como a pobreza, a falta de estrutura emocional, a falta de instrução, sendo esta última o agente potencializador que leva a doméstica a se deixar ser objetificada pelo filho dos patrões.

\section{Referências}

BACHELARD, Gaston. A terra e os devaneios do repouso: ensaio sobre as imagens da intimidade. Trad.: Paulo Neves, 2. ed. São Paulo: Martins Fontes, 2003.

BADINTER, Elizabeth. Um amor conquistado: o mito do amor materno. Trad.: Waltensir Dutra. Rio de Janeiro: Nova Fronteira, 1985.

BADINTER, Elizabeth. O conflito: a mulher e a mãe. Trad.: Véra Lucia dos Reis. Rio de Janeiro: Record, 2011.

BEAUVOIR, Simone de. O segundo sexo: fatos e mitos, volume 1. Tradução de Sérgio Milliet. 3. ed. Rio de Janeiro: Nova Fronteira, 2016a.

BEAUVOIR, Simone de. O segundo sexo: a experiência vivida, volume 2. Tradução de Sérgio Milliet. 3. ed. Rio de Janeiro: Nova Fronteira, 2016b. 
BÍBLIA. Português. Velho Testamento e Novo Testamento. Tradução de Ivo Storniolo e Euclides Martins Balancin. São Paulo: Paulus, 1998.

BOURDIEU, Pierre. A dominação masculina. Trad.: Maria Helena Küher. 13. ed. Rio de Janeiro: Bertrand, 2015.

CHEVALIER, Jean; GHEERBRANT, Alain. Dicionário de símbolos: Mitos, sonhos, costumes, gestos, formas, figuras, cores, números. Trad.: Vera da Costa e Silva [et. al.]. 27. ed. Rio de Janeiro: José Olympio, 2015.

CHODOROW, Nancy. Psicanálise da maternidade: uma crítica a Freud a partir da mulher. Trad.: Nathanael C. Caixeiro. 2. ed. Rio de Janeiro: Record: Rosa dos Tempos, 2002.

DONATH, Orna. Mães arrependidas: uma outra visão da maternidade. Trad.: Marina Vargas. 1a. ed. Rio de Janeiro: Civilização Brasileira, 2017.

ESTÉS, Clarissa Pinkola. Mulheres que correm com os lobos: mitos e histórias do

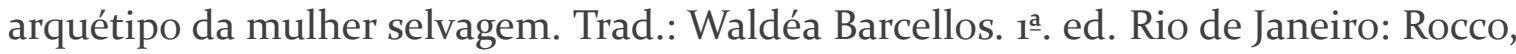
2018.

HILFERDING, Margareth. As bases do amor materno. Trad.: Teresa Pinheiro. São Paulo: Escuta, 1991.

IACONELLI, Vera. Mal-estar na maternidade: do infanticídio à função materna. São Paulo: Annablume, 2015.

KAMERS, Michele. As novas configurações da família e o estatuto simbólico das funções parentais. Estilo da Clínica. São Paulo. v. 11, n. 21, dez. 2006, p. 108-125.

LEITE, Tayná. Gestar, parir, amar: não é só começar. Belo Horizonte: Letramento, 2019 .

MURARO, Rose Marie. A mulher no terceiro milênio. Rio de Janeiro: Editora Rosa dos Tempos, 2002.

SILVEIRA, Maria José. A mãe da mãe da sua mãe e suas filhas. São Paulo: Globo, 2002.

SAAVEDRA, Carola. Com armas sonolentas. São Paulo: Companhia das Letras, 2018

Recebido em 18/03/2021.

Aceito em 01/06/2021. 